CZASOPISMO INŻYNIERII LĄDOWEJ, ŚRODOWISKA I ARCHITEKTURY JOURNAL OF CIVIL ENGINEERING, ENVIRONMENT AND ARCHITECTURE

JCEEA, t. XXXIV, z. 64 (4///17), październik-grudzień 2017, s. 351-362, DOI:10.7862/rb.2017.219

\author{
Marek NALEPKA ${ }^{1}$
}

\title{
MONITOROWANIE USZKODZEŃ W RAMIE ŻELBETOWEJ
}

\begin{abstract}
W artykule przestawiono próbę wytypowania współczynników, które dodatkowo poza obrazem współczynników falkowych pozwalałyby stwierdzić, czy w konstrukcji doszło do postępującego uszkodzenia względem znanego stanu oraz wpływu uszkodzenia na konstrukcję (spadku właściwości dynamicznych). W celu określenia wpływu uszkodzenia na odpowiedź konstrukcji posłużono się numerycznym modelem żelbetowej ramy portalowej poddanej testom o wzrastającej sile wymuszenia sejsmicznego podłoża. Wykorzystano w modelu nieliniowość konstrukcji w formie nieliniowości materiałowej (nieliniowe związki konstytutywne) jak i geometrycznej. Odpowiedź przyśpieszeniową konstrukcji przetworzono za pomocą ciągłej transformaty falkowej (z wykorzystaniem falki-matki Morlet) reprezentującej analizowany sygnał w dziedzinie czasowo-częstotliwościowej. Określone współczynniki (pikowy, asymetrii oraz rozproszenia) wytypowane na podstawie zapisu odpowiedzi z użyciem transformaty falkowej pomogły określić chwilę czasową wystąpienia uszkodzenia i spadek sztywności uszkodzonej konstrukcji odzwierciedlony w spadku jej częstotliwości drgań własnych. Następnie za pomocą wytypowanych współczynników przeanalizowano zapis odpowiedzi ramy żelbetowej badanej doświadczalnie, która poddana została testom na stole wstrząsowym w ISMES, które miały na celu określenie wpływu uszkodzenia na właściwości dynamiczne konstrukcji żelbetowych. Zaproponowane współczynniki pozwoliły na powiązanie zmiany ich wartości z powstałym uszkodzeniem poprzez porównanie zmiany właściwości dynamicznych ze zmianą wytypowanych współczynników wrażliwych na uszkodzenie. Współczynnik pikowy bezpośrednio powiązany z częstotliwością drgań własnych wskazywał chwilę czasowa wystąpienia uszkodzenia, zmienne wartości współczynnika asymetrii $\mathrm{i}$ rozproszenia wskazały trend zmian wraz z rozwojem tego uszkodzenia.
\end{abstract}

Słowa kluczowe: nieliniowa praca konstrukcji, analiza falkowa, właściwości dynamiczne, odpowiedź konstrukcji, transformata falkowa

\section{Wstęp}

Monitorowanie i wykrywanie uszkodzeń konstrukcji (SHM - Structural Health Monitoring) jest współczesnym wyzwaniem inżynierskim, które może wpływać istotnie na bezpieczeństwo użytkowania obiektów budowlanych.

\footnotetext{
${ }^{1}$ Marek Nalepka, Politechnika Opolska, Katedra Mechaniki, Konstrukcji Budowlanych i Inżynierskich, ul. Prószkowska 76, 45-758 Opole; tel. 774498000; m.nalepka@po.opole.pl
} 
Wpływ trzęsienia ziemi na konstrukcję, z uwagi na swój nagły charakter oddziaływania i katastrofalne skutki jakie wywołać mogą uszkodzenia, jest bardzo ważnym zagadnieniem współczesnej inżynierii. Natychmiastowe rozpoznanie uszkodzenia, jego lokalizacji i wielkości, jest kluczowe przy ocenie zagrożenia i zapobieganiu dalszym stratom i propagacji uszkodzeń, wpływa również bezpośrednio na decyzję dotyczącą napraw i renowacji obiektów. Stosowane aktualnie metody monitorowania konstrukcji wymagają jednak stałego dostępu do konstrukcji i miejsca w którym uszkodzenie mogło wystąpić. Ograniczenia te doprowadziły do opracowania technik monitorowania konstrukcji i detekcji uszkodzeń w oparciu o zmiany charakterystyk dynamicznych konstrukcji, np. poprzez pomiar drgań $[1,2]$.

\section{Analiza częstotliwościowa odpowiedzi konstrukcji}

Analiza modalna przeprowadzana jest $\mathrm{w}$ dziedzinie czasu, dlatego większość obecnych systemów SHM wdraża zastosowanie transformaty Fouriera (FT - Fourier Transform). FT jest używana do rozkładu sygnału w dziedzinie czasu w celu określania głównych charakterystyk dynamicznych konstrukcji, takich jak częstotliwość drgań własnych. Problemem w stosowaniu FT jest to, że wynikiem analizy jest podsumowanie charakterystyki dynamicznej na całej długości sygnału, natomiast nie ma możliwości określenia miejsca w którym charakterystyka dynamiczna sygnału mogła ulec zmianie [3].

\subsection{Ciągła transformata falkowa}

Narzędziem, które bazuje na FT jest bezpośrednim rozwinięciem tych metod, jest transformata falkowa. Ciaggła transformata falkowa (CWT - Continuous Wavelet Transform) sygnału, w dziedzinie czasu zdefiniowana jest w następujący sposób:

$$
C W T(t, a)=\frac{1}{\sqrt{|a|}} \int_{-\infty}^{\infty} x(\tau) \gamma\left(\frac{\tau-t}{a}\right) d \tau
$$

gdzie: $\quad t$ - chwila czasowa badanego sygnału;

$x(\tau)$ - analizowany sygnał;

$y(t)$ - bazowa funkcja filtrująca, tzw. funkcja matka;

$a$ - skala funkcji matki.

Transformata falkowa, odgrywa znaczącą rolę w wykrywaniu uszkodzeń w konstrukcji. Zastosowanie odpowiedniej rodziny funkcji bazowej filtrującej sygnał (tzw. matki falki) pozwala wykryć chwilową zmienność sygnału poddanego analizie [4]. Analizowanym sygnałem może być dowolna wielkość, będąca odpowiedzią konstrukcji na obciążenie, np. krzywizna elementu [5] czy zapis przyspieszeń [6]. Dodatkową zaletą stosowania CWT jest wykrywanie zmienno- 
ści analizowanej wielkości i/oraz, w zależności w jakiej dziedzinie jest poddawana analizie odpowiedź, wyznaczenie lokalizacji lub chwili czasowej powstania uszkodzenia [7]. W analizie sygnałów odpowiedzi, uzyskanych poprzez symulacje dynamiczne, wybrano falkę matkę tzw. Morlet wavelet, która została pierwotnie wprowadzona do analizy zapisów sejsmicznych [8]. Falka Morlet używana jest obecnie $\mathrm{w}$ różnych zastosowaniach, w tym z powodzeniem do mechanicznego diagnozowania uszkodzeń $[5,6]$.

\section{Opis uszkodzeń konstrukcji przy użyciu CWT}

Analiza CWT sygnału odpowiedzi pozwala graficzne przedstawić odpowiedź konstrukcji (w formie skalogramu), w związku z tym analiza obrazu współczynników falkowych może bezpośrednio informować o zachowaniu się konstrukcji pod wpływem uszkodzenia. Częstotliwość drgań własnych konstrukcji odzwierciedlona jest w obrazie pików wartości współczynnika falkowego $[6,9,10]$. Na tej podstawie sformułowano współczynnik pikowy (PC-Peak Coefficient). Informacja o uszkodzeniu bezpośrednio może odzwierciedlać się
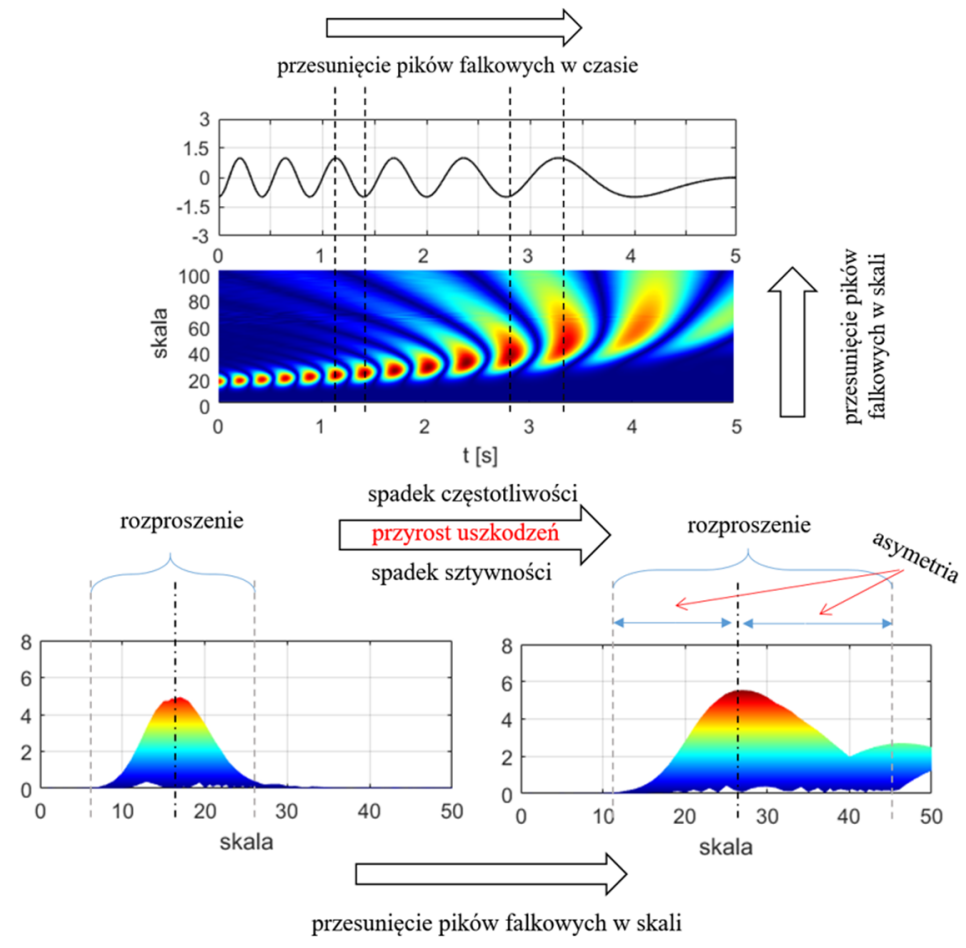

Rys. 1. Przebieg zmienności przestrzennego obrazu współczynników falkowych w zależności od propagacji uszkodzenia

Fig. 1. Changes in the scalogram of wavelet coefficient according to the damage propagation 
w rozproszeniu współczynnika falkowego. W tym celu wytypowano współczynnik rozproszenia (DC - Dispersion Coefficient). Analogiczne sformułowany został współczynnik asymetrii (AC - Asymmetry Coefficient), który obrazuje niesymetryczne rozproszenie współczynnika falkowego w skali (rys. 1).

\section{Symulacja numeryczna}

W celu rozpoznania możliwości stosowania powyższych współczynników wrażliwych na uszkodzenie posłużono się programem OpenSees przeznaczonym głównie do modelowania konstrukcji w zakresie nieliniowym (geometrycznym jak i materiałowym) obciążonych w sposób dynamiczny [11]. Model numeryczny zastosowany do wytypowania współczynników stanowiła żelbetowa rama portalowa (rys. 2). Rygiel ramy został przyjęty jako element o nieskończonej sztywności w celu koncentracji wpływu zginania na słupy. W modelowaniu przekroju poprzecznego słupów ramy wykorzystano materiały o nieliniowych związkach konstytutywnych: steel01 [12] dla stali zbrojeniowej, conrete02 [13] dla żelbetu (nazewnictwo zaczerpnięte $\mathrm{z}$ biblioteki programu).

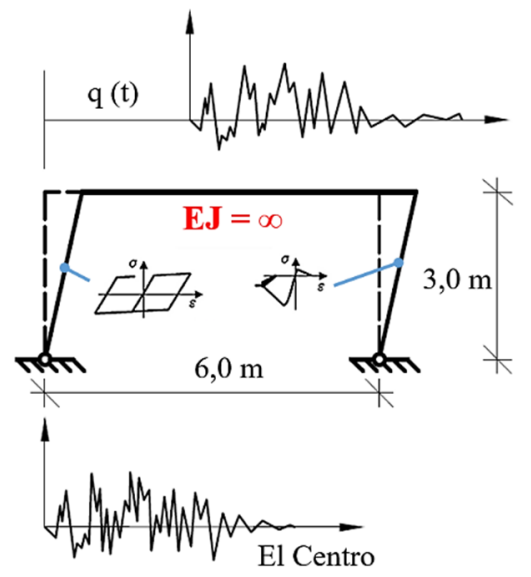

Rys. 2. Analizowana rama portalowa

Fig. 2. Analyzed portal frame

Symulacja numeryczna polegała na analizie czasowej konstrukcji (Time History Analysis) z wykorzystaniem wzorcowego wymuszenia sejsmicznego El Centro [14]. Analizę przeprowadzano etapami. Każdy etap polegał na zwiększeniu siły wymuszenia w celu osiągnięcia uszkodzenia w konstrukcji. Wyniki przedstawione na rys. 3 i 4 przedstawiają wykresy zmienności współczynników falkowych i wytypowanych współczynników wrażliwych na uszkodzenie (punkt 3) dla wybranych trzech stanów uszkodzenia: ramy nieuszkodzonej (odpowiedź liniowa), umiarkowanego uszkodzenia oraz silnego uszkodzenia, powyżej którego w modelu numerycznym dochodziło do zniszczenia konstrukcji. 


\subsection{Współczynniki wrażliwe na uszkodzenie}

Odpowiedź konstrukcji (w zakresie przyspieszeń) uzyskana z wytypowanych stanów uszkodzenia została poddana analizie CWT w celu pozyskania i potwierdzenia słuszności wytypowania współczynników wrażliwych na uszkodzenie.

Wykresy zapisu przyspieszeń konstrukcji przedstawiono na rys. $3 \mathrm{a}$ wraz z wykresami przedstawiającymi obraz współczynników falkowych (skalogramów) (rys. 3b). Wykresy wytypowanych współczynników wrażliwych na uszkodzenie przedstawiono na rys. $3 \mathrm{c}, 4 \mathrm{a}$ oraz na rys. $4 \mathrm{~b}$.

Współczynnik PC przedstawiono na rys 3c. Śledzenie przemieszczenia pików falkowych pozwala zaobserwować chwile wystąpienia uszkodzenia, którego efektem jest spadek częstotliwości drgań własnych i tym samym przesunięcie w piku falkowego w dziedzinie skali.

Współczynnik DC przedstawiono na rys. 4a, wykres przedstawia wartości współczynnika dla całego sygnału, oraz wartości współczynnika zawężone do pików falkowych z wartością średnią (czerwona linia). Zauważyć można ze rozwój uszkodzenia wpływa na wzrost wartości współczynnika (zmiana wartości dla poszczególnych pików falkowych oraz średniej wartości współczynnika).

Wartości współczynnika AC pokazano na rys. 4b. Współczynnik AC nie wskazuje bezpośrednio chwili wystąpienia uszkodzenia można stwierdzić, że wpływ uszkodzenia uwidacznia się w spadku wartości współczynnika. Wartości średnie współczynników DC i AC wraz z wartością główną częstości drgań własnych zestawiono $\mathrm{w}$ tabeli 1.

Tabela 1. Zmienność podstawowej częstotliwości drgań własnych oraz średnich wartości współczynników wrażliwych na uszkodzenie

Table 1. Variability of the first natural frequency of portal frame connected to the mean values of the damage-sensitive coefficient

\begin{tabular}{|c|l|c|c|c|}
\cline { 3 - 4 } \multicolumn{2}{c|}{} & $\begin{array}{c}\text { Nieuszkodzona } \\
\text {,intact” }\end{array}$ & $\begin{array}{c}\text { Uszkodzenie } \\
\text { umiarkowane }\end{array}$ & $\begin{array}{c}\text { Silne uszko- } \\
\text { dzenie }\end{array}$ \\
\hline 1. & $\begin{array}{l}\text { Częstotliwość drgań wła- } \\
\text { snych, [Hz] }\end{array}$ & 1,02 & 0,86 & 0,75 \\
\hline 2. & Współczynnik DC & 0,198 & 0,292 & 0,379 \\
\hline 3. & Współczynnik AC & 3,592 & 2,983 & 2,531 \\
\hline
\end{tabular}


a)
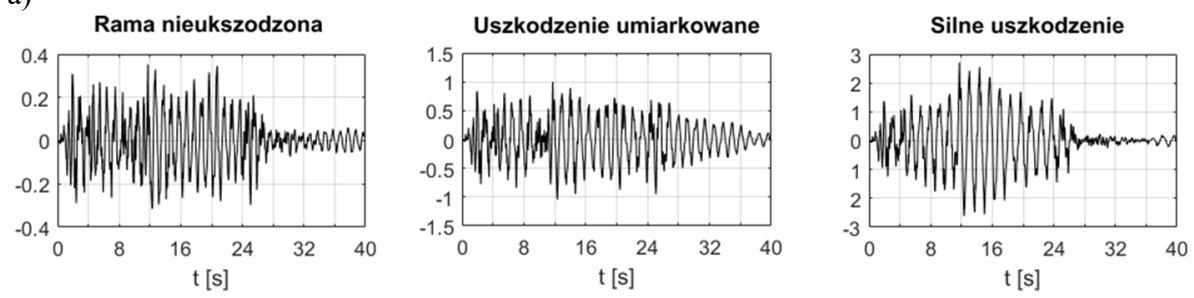

b)
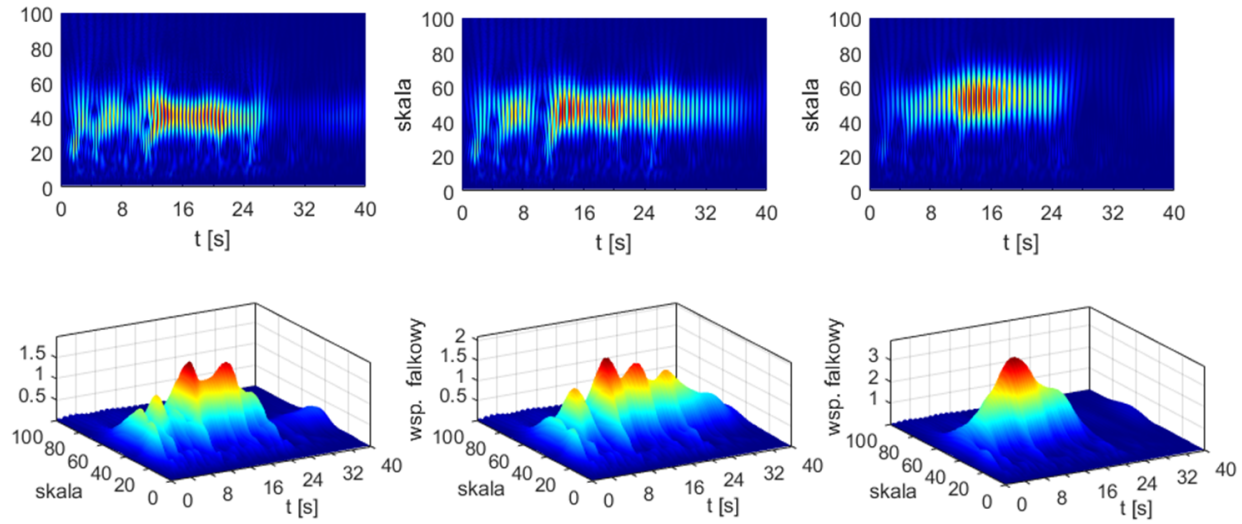

c)
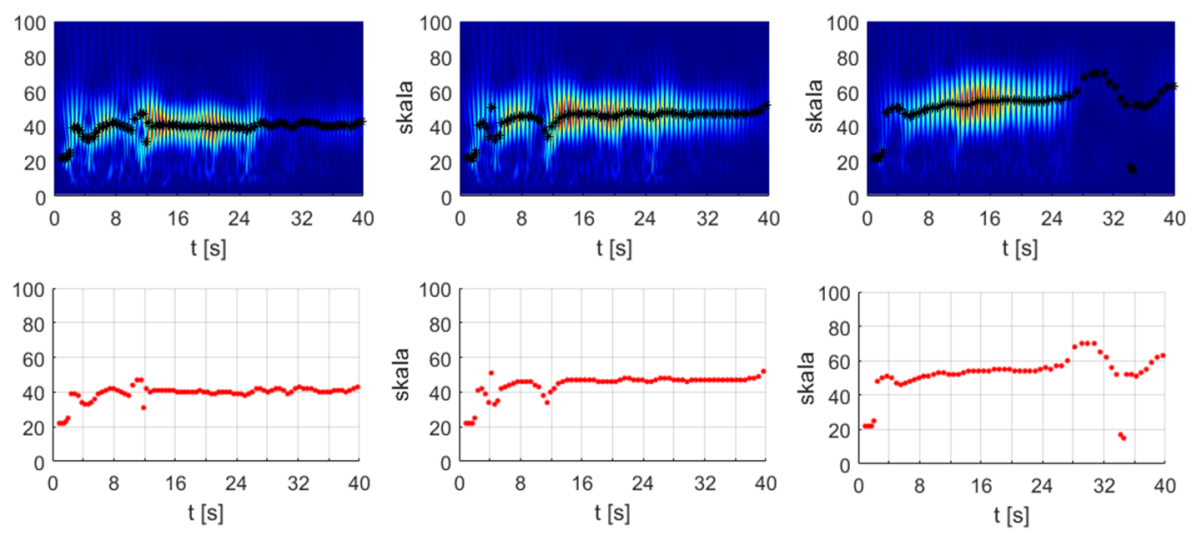

Rys. 3. Wykresy: a) zapis odpowiedzi konstrukcji b) skalogram - przestrzenny obraz współczynników falkowych w dziedzinie czasu i skali c) przebieg zmiany położenia pików falkowych współczynnik PC

Fig. 3. Graphs: a) response of the structure b) scalogram - spatial image of wavelet coefficients in the time and scale domain c) shift of the wavelet peak - Peak Coefficient 
a)

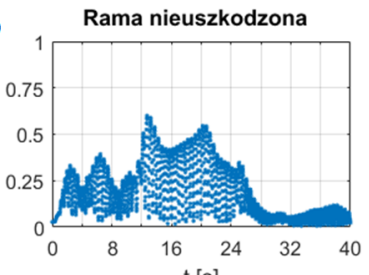

$\mathrm{t}[\mathrm{s}]$

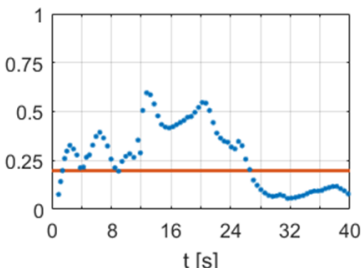

b)
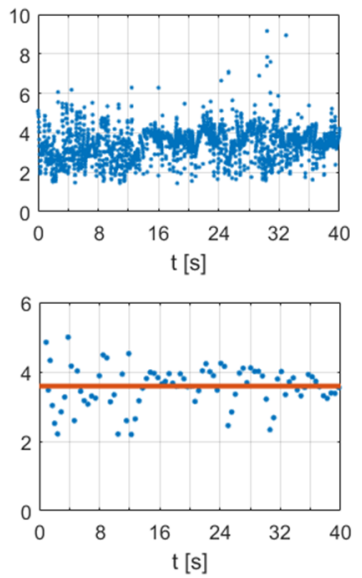

Uszkodzenie umiarkowane

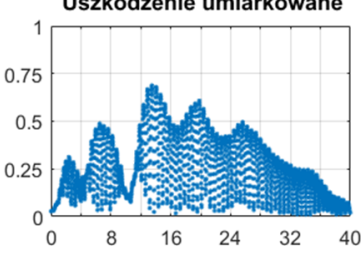

$\mathrm{t}[\mathrm{s}]$
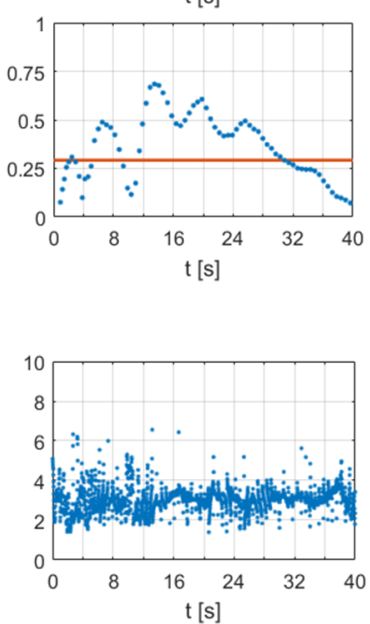

$\mathrm{t}[\mathrm{s}]$

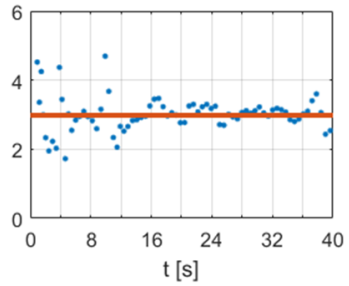

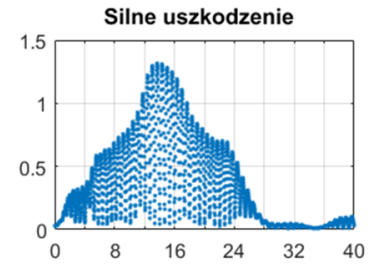

$\mathrm{t}[\mathrm{s}]$
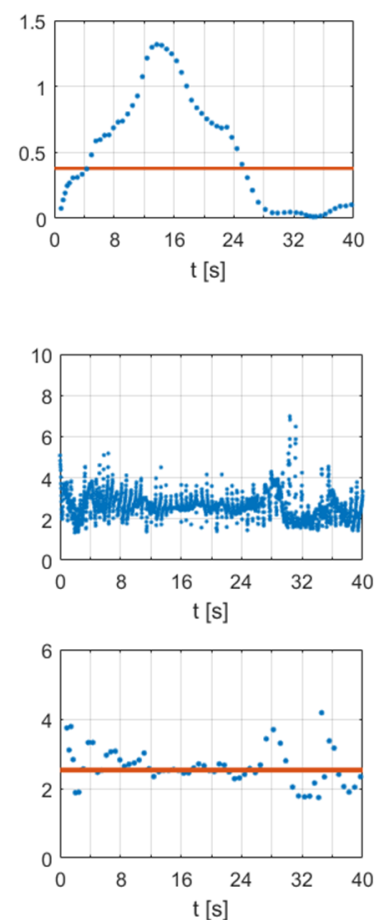

Rys. 4. Współczynniki wrażliwe na uszkodzenie dla trzech wytypowanych stanów uszkodzenia: a) wartości współczynnika DC oraz b) wartości współczynnika AC

Fig. 4. Damage-sensitive coefficient of the three chosen stages of damage: a) Dispersion Coefficient and b) Asymmetry Coefficient value (mean value - line)

\section{Eksperyment}

W latach 90. XX w. w Instytucie Mechaniki Eksperymentalnej (ISMES, Bergamo, Włochy) przeprowadzono eksperyment, który miał na celu określić wpływ zarysowania konstrukcji żelbetowych na ich charakterystyki dynamiczne. Badanie przeprowadzono na konstrukcji ramowej o wymiarach (w rzucie) $3,4 \times 3,4 \mathrm{~m}$ oraz wysokości $4,15 \mathrm{~m}$. Konstrukcja posiadała jedną oś symetrii z uwagi na występowanie dwóch rodzajów słupów $0,2 \times 0,2 \mathrm{~m}$ oraz $0,2 \times 0,4 \mathrm{~m}$ (rys. 5 ). Do budowy użyto betonu odpowiadającego klasie $\mathrm{C} 30 / 37$ oraz stali zbrojeniowej włoskiej produkcji (Fe44K) [15]. 


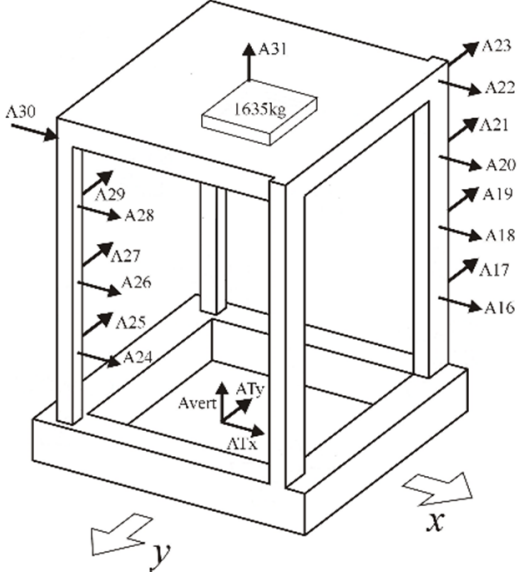

Rys. 5. Schemat analizowanej ramy żelbetowa na stole wstrząsowym z rozmieszczeniem akcelerometrów, na podstawie [15]

Fig. 5. Scheme of analysed $\mathrm{r} / \mathrm{c}$ frames on the shaking table with locations of accelerometers, based on [15]

Eksperyment polegal na poddawaniu ramy pewnemu wymuszeniu sejsmicznemu na kierunkach x, y o zwiększającej się intensywności określonej przez odpowiedni mnożnik zapisów przyspieszeń. Otrzymano kolejne stany uszkodzenia opisane przez szczytowe przyspieszenia wymuszeń (PGA - Peak Ground Accelerations) wynoszące od $35,6 \mathrm{~cm} / \mathrm{s}^{2}$ do $1090 \mathrm{~cm} / \mathrm{s}^{2}$ (tab. 2) [15].

Tabela 2. Zmiany częstotliwości własnych w miarę rozwoju uszkodzenia, na podstawie [15]

Table 2. Changes in natural frequencies releted to structural damage propagated, based on [15]

\begin{tabular}{|c|c|c|c|c|}
\hline \multirow{2}{*}{ Lp. } & Poziom wymuszeń & $\mathbf{f}_{\mathbf{1}}$ & $\mathbf{f}_{\mathbf{3}}$ & $\mathbf{f}_{\mathbf{2}}$ \\
\cline { 3 - 5 } & & $\mathrm{Hz}$ & $\mathrm{Hz}$ & $\mathrm{Hz}$ \\
\hline $\mathbf{1 .}$ & Rama nieuszkodzona (stan ,,0”) & $\mathbf{4 , 6 9}$ & $\mathbf{5 , 3 2}$ & $\mathbf{1 0 , 1 6}$ \\
\hline 2. & Stan „I”- PGA $=146 \mathrm{~cm} / \mathrm{s}^{2}$ & 4,20 & 4,98 & 9,77 \\
\hline 3. & Stan „II”- PGA $=319 \mathrm{~cm} / \mathrm{s}^{2}$ & 2,83 & 3,61 & 7,52 \\
\hline $\mathbf{4 .}$ & Stan „III”- PGA $=\mathbf{4 1 3} \mathrm{cm} / \mathrm{s}^{2}$ & $\mathbf{2 , 4 4}$ & $\mathbf{3 , 2 2}$ & $\mathbf{6 , 5 4}$ \\
\hline 5. & Stan „IV”- PGA $=644 \mathrm{~cm} / \mathrm{s}^{2}$ & 2,09 & 2,54 & 5,47 \\
\hline 6. & Stan „V”- PGA $=843 \mathrm{~cm} / \mathrm{s}^{2}$ & 1,76 & 2,15 & 4,69 \\
\hline $\mathbf{7 .}$ & Stan „VI”- PGA $=\mathbf{1 0 9 0} \mathrm{cm} / \mathrm{s}^{2}$ & $\mathbf{1 , 4 6}$ & $\mathbf{1 , 8 6}$ & $\mathbf{3 , 8 1}$ \\
\hline
\end{tabular}

\subsection{Współczynniki wrażliwe na uszkodzenie}

Do analizy przydatności wytypowanych współczynników posłużono się zapisem odpowiedzi pochodzącym z czujnika A22 (lokalizacja według rys. 5) dla 3 stanów uszkodzenia: intact (rama nieuszkodzona), stan „III” (PGA $=413 \mathrm{~cm} / \mathrm{s}^{2}$ ) oraz stan 'VI' (PGA $=1090 \mathrm{~cm} / \mathrm{s}^{2}$ ) (pogrubiona czcionka tabela 2). Odpowiedź konstrukcji została poddana analizie CWT z użyciem bazowej funkcji filtrującej - falki Morlet. 

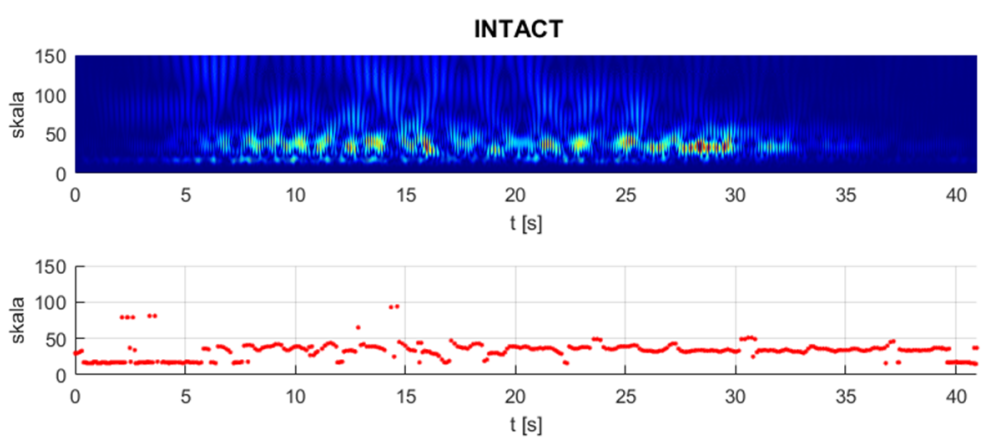

STAN „III”
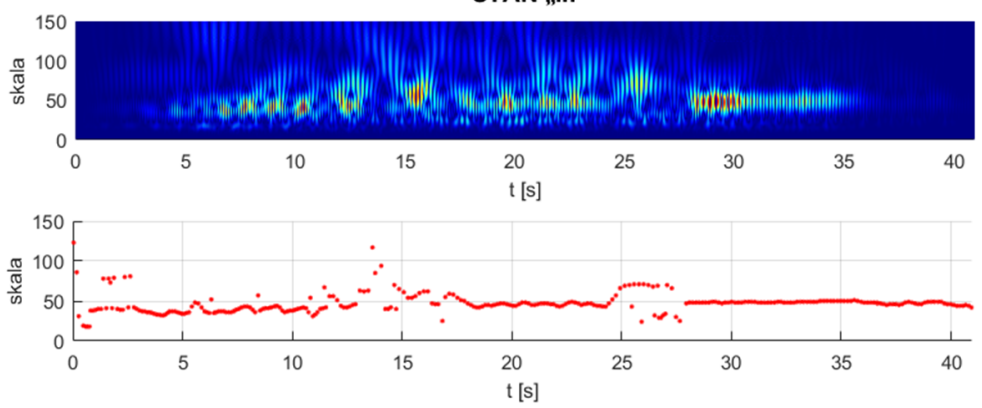

STAN ,VI”

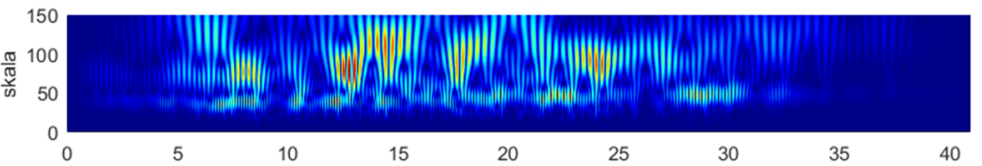

$\mathrm{t}[\mathrm{s}]$

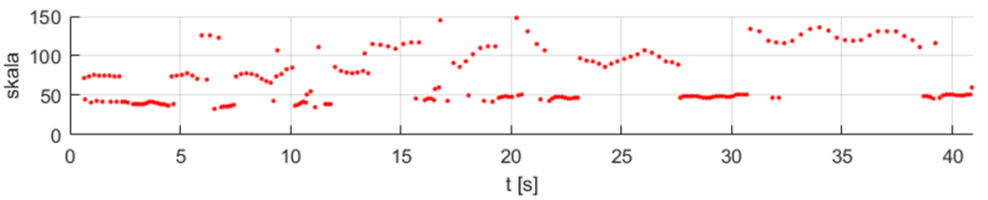

Rys. 6. Skalogram współczynników falkowych odpowiedzi ramy żelbetowej (czujnik A22) dla wytypowanych stanów uszkodzenia wraz z współczynnikiem PC

Fig. 6. Scalogram of wavelet coefficients of reinforced concrete frame response (accelerometer A22) for selected stages of damage with the Peak Coefficient

Scalogramy współczynników falkowych wraz ze współczynnikiem PC przedstawiono na rys. 6 . Wraz z rozwojem uszkodzenia zauwazyć można rozprzestrzenie się pików w skali, które związane jest z spadkiem sztywności i tym samym spadkiem częstotliwości drgań własnych konstrukcji (rys. 6). W odróżnieniu od wykresu zmiany położenia pików w symulacji numerycznej (rys. 3c) widoczne są główne pasma pików, które odpowiadają głównym dominującym częstotliwościom drgań układu. Wykresy zmienności współczynnika DC i współczynnika $\mathrm{AC}$ również zawężono do wartości dopowiadających pików 
falkowych, na wykresach zaznaczono również wartości średnie współczynników (rys. 7). Zmiana wartości współczynnika DC oraz wspołczynnika AC potwierdza zauważony trend zmian postępujący z uszkodzeniem: wartość współczynnika DC wraz z rozwojem uszkodzenia (którego efektem jest rozproszeniem falki w skali, czyli spadek sztywności) wzrasta, natomiast współczynnik AC, zgodnie z założeniem maleje.

Porówanie spadku pierwszej częstotliwości drgań własnych (powiązanej ze spadkiem sztywności) z wartościami średnimi współczynników DC i AC zestawiono w tabeli 3 .
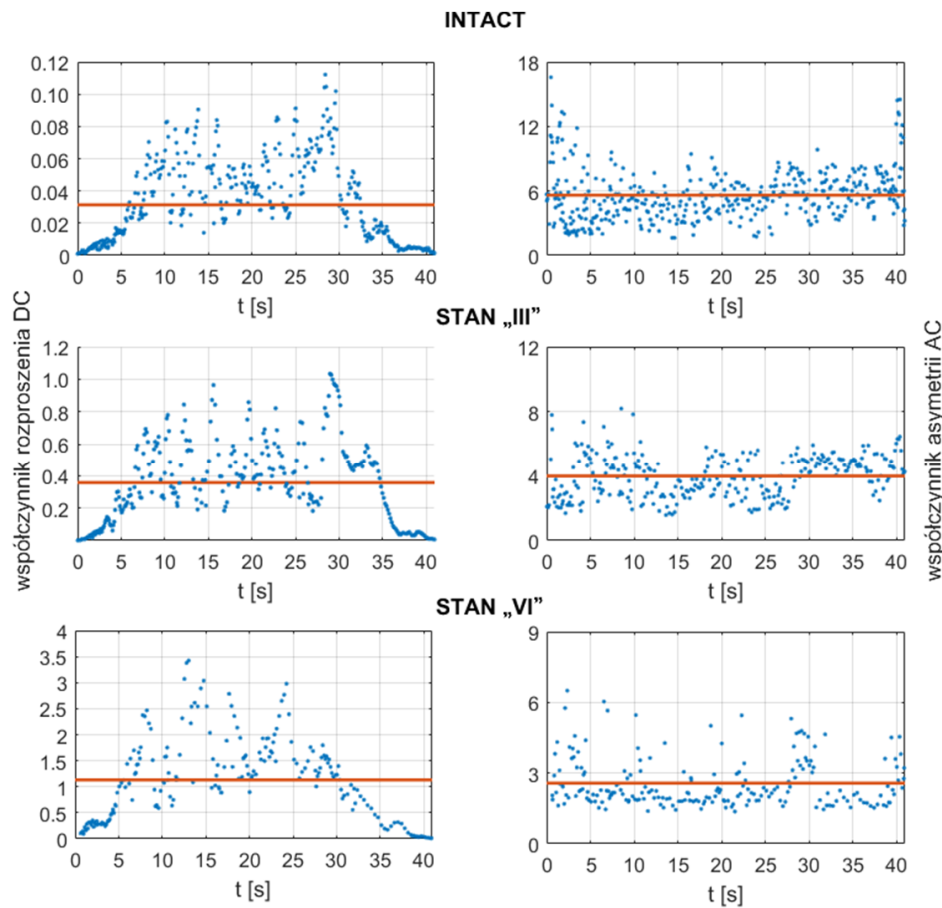
STAN ,VI"

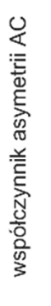

Rys. 7. Współczynnik DC oraz AC wraz z wartością średnią

Fig. 7. Dispersion and Asymmetry Coefficient (mean value - line)

Tabela 3. Zmienność pierwszej częstotliwości drgań własnych oraz średnich wartości współczynników wrażliwych na uszkodzenie

Table 3. Changes of the first natural frequency and mean values of the sensetive-damage coefficient

\begin{tabular}{|c|l|c|c|c|}
\cline { 3 - 5 } \multicolumn{2}{c|}{} & „Intact” & Stan ‘III' & Stan 'VI' \\
\hline 1. & Pierwsza częstotliwość drgań własnych & $4,69 \mathrm{~Hz}$ & $2,44 \mathrm{~Hz}$ & $1,46 \mathrm{~Hz}$ \\
\hline 2. & Współczynnik DC & 0,032 & 0,389 & 1,132 \\
\hline 3. & Współczynnik AC & 5,607 & 3,978 & 2,572 \\
\hline
\end{tabular}




\section{Podsumowanie i wnioski}

W artykule przestawiono próbę wytypowania współczynników, które poza obrazem współczynników falkowych pozwalałyby stwierdzić, czy w konstrukcji doszło do postępującego uszkodzenia względem znanego stanu: współczynnik pikowy(PC), współczynnik rozproszenia (DC) oraz współczynnik asymetrii (AC).

W celu określenia przydatności wytypowanych współczynników posłużono się modelem żelbetowej ramy portalowej z wykorzystaniem materiałów o nieliniowych związkach konstytutywnych. Współczynnik pikowy (PC) bezpośrednio "śledzi" zmiany wartości częstotliwości drgań własnych konstrukcji i może być wykorzystany z powodzeniem to wykrywania zmian w sztywności konstrukcji. Współczynnik rozproszenia (DC) wyraźnie wskazuje na wzrost wartości wraz z rozwojem uszkodzenia. Porównanie wartości współczynnika przy początkowych stanach uszkodzenia może wskazać chwilę czasową wystąpienia tego uszkodzenia. Współczynnik asymetrii (AC) wraz z rozwojem uszkodzenia wykazuje spadek swojej wartości. Przydatność zastosowania współczynników sprawdzono również dla odpowiedzi konstrukcji badanej eksperymentalnie. Trend zauważony przy analizie prostej ramy potwierdza się w przypadku eksperymentu, jednakże w przypadku współczynnika DC, nie można bezpośrednio określić chwili czasowej wystąpienia uszkodzenia $\mathrm{z}$ uwagi na zaszumienie sygnału.

Zastosowanie ciągłej transformaty falkowej może być z powodzeniem wykorzystywane do analizy i detekcji uszkodzeń. Zauważyć można zależność pomiędzy wystąpieniem uszkodzenia w konstrukcji a wartościami współczynników falkowych i wytypowanych współczynników wrażliwych na uszkodzenie. Wykazany w artykule trend zależności potwierdza główny kierunek analiz, które mogą doprowadzić do stworzenia narzędzi wykorzystywanych do automatycznej diagnozy konstrukcji.

\section{Literatura}

[1] Spanos P.D., Giaralis A., Politis N.P., and Roesset J.M., Numerical treatment of seismic accelerograms and of inelastic seismic structural responses using harmonic wavelets. Computer-Aided Civil and Infrastructure Engineering, 22(4), 2007, pp. 254-264.

[2] Wilde K., Modal diagnostics, of civil engineering structures, Gdańsk University of Technology Publishers, Gdańsk 2008.

[3] Bracewell R., Przekształcenie Fouriera I jego zastosowania, Wydawnictwo NaukowoTechniczne, Warszawa, 1965.

[4] Bałasiewicz J.T., Falki i aproksymacje, Wydawnictwo Naukowo-Techniczne, Warszawa, 1965.

[5] Rucka M., Wilde K., Application of continuous wavelet transform in vibration based damage detection method for beams and plates, Journal of Sound and Vibration, 297, 2006, pp. 536-550.

[6] Noh H.Y., Nair K., Lignos D. G., Kiremijdian A.S.Z., Kowalski M., Pospisil S., Use of wavelet-based damage-sensitive features for structural damage diagnosis using strong motion data, Journal Engineering Structures, vol. 137(10), 2011, pp. 1215-1228. 
[7] Spanos P. D., Failla G., Wavelets: Theoretical concepts and vibrations related applications, The Shock and Vibration Digest, 37(5), 2005, pp. 359-75.

[8] Morlet J., Arens G., Fourgeau E., Giand D., Wave propagation and sampling theory, Geophysics 47(2), 1982, pp. 203-236.

[9] Balafas K., Kiremijdian A.S., Development and validation of a novel earthquake damage estimation scheme based on the continuous wavelet transform of input and output acceleration measurements,Earthquake Engineering and Structural Dynamics, vol. 44(4), 2014 pp. 1215-1228.

[10] Nair K.K., Kiremidjian A.S.Z., Damage diagnosis algorithm for wireless structural health monitoring, Earthquake Engineering Center, Departament of Civil Engineering, Standord University, California.

[11] http://opensees.berkeley.edu/ \{dostęp: 10.02.2017 r.\}.

[12] Filippou F.C., Popov E.P, Bertero V.V, Effects of bond deterioration on hysteretic behavior of reinforced concrete joints, Report EERC 83-19, Earthquake Engineering Research Center, University of California, Berkeley, 1994.

[13] Mohd H., Mohd Y., Nonlinear Analysis of prestressed concrete structures under monotonic and cycling loads, PhD dissertation, University of California, Berkeley, 1994.

[14] http://www.vibrationdata.com/elcentro.htm \{dostęp: 10.02.2017 r.\}.

[15] Zembaty Z., Kowalski M., Pospisil S., Dynamic identification of a reinforced concrete frame in progressive states of damage, Engineering Structure 28, 2006, pp. 668-681.

\section{DAMAGE MONITORING OF A REINFORCED CONCRETE FRAME}

\section{S u m m a r y}

This papier introduces wavelet based damage-sensitive coefficient extracted from structural response and used to correlate the damage propagation with changes in scalogram of a wavelet coefficient. In order to determine the effect of damage on the structural response, an inelastic numerical model of a reinforced concrete portal frame subjected with increasing seismic excitation has been used. The response of the structure has been processed by Continuous Waveform Transform (using Morlet wavelet as a mother wavelet) representing the analyzed signal in the time-frequency domain. Specific wavelet-based factors (Peak, Dispersion, and Asymmetry Coefficient) helped to determine the moment when the damage occurred in structure (a reduce in stiffness of the structure reflected in the fall of its natural frequency), to confirm the relation between the value of the coefficient and the damage state the response of the experimental reinforced concrete test frame was analyzed. Wavelet analyses of the response records of the $\mathrm{r} / \mathrm{c}$ analyzed frame reveal clear, characteristic changes in the development of the wavelet ridges and peak patterns from the moment the structure starts to accumulate damage. The Peak coefficient directly "follows" the damage by observing the trace of peaks which correspond to natural frequency, it shows a changes in structural stiffness. The Dispersion and Asymmetry Coefficient has clearly shown that with the spread of frequency content the value of coefficient changes.

Keywords: nonlinear structure, wavelet analysis, dynamic properties, structural response, wavelet transform 